\title{
AVAILABILITY, OVERLAP AND COST OF QUALITY JOURNAL SUBSCRIPTIONS IN COMPUTER SCIENCE
}

\author{
A.N. Zainab ${ }^{1}$ and S.L. $\mathrm{Ng}^{2}$ \\ ${ }^{1}$ Faculty of Computer Science \& Information Technology, \\ University of Malaya, 50603 Kuala Lumpur, Malaysia \\ 2 Library, Taylors College, Subang Jaya Malaysia. \\ E-mail: zainab@um.edu.my; slng_99@yahoo.com
}

\begin{abstract}
This study describes the availability of quality journals held at the University of Malaya Library (UML) in the field of computer science and compares this to the availability of journal collections in four other university libraries: Science University of Malaysia (USM), University of Technology Malaysia (UTM), National University of Malaysia (UKM), and University Putra Malaysia (UPM). All the universities included in the study have been established for more than fifteen years and offer degree programmes in computer science. Quality journals refer to the 301 titles with impact-factor scores listed in the Journal Citation Report 1999 (JCR) in the field of computer science. The study also investigates the degree of journal overlap among the five university libraries. The UML was taken as a case study to show how overlap titles are ascertained and costs calculated. The results indicate that (a) UML holdings of quality journal titles is poor and that a similar pattern is indicated in the other university libraries $(34.22 \%$ by UML, $40 \%$ by UTM, $16 \%$ by UKM, $31 \%$ by USM, and $23 \%$ by UKM); (b) for the five libraries, out of the 301 titles, $115(38.2 \%)$ overlap, 96 titles (32.23\%) are singly-held titles, and 84 titles are not subscribed to; (c) the percentage of overlap is related to the size of title availability; (d) the cost of journal title overlap for UML is estimated to be about U.S.\$79,650.40, and the cost of the titles not subscribed to is U.S.\$41,440.32. It is proposed that cooperative subscription ventures would help reduce costs and release monies to cover the other quality titles not subscribed to by any of the libraries.
\end{abstract}

Keywords: Journal duplicates, journal overlap, computer science, impact factor, collection development, serials costing.

\section{AVAILABILITY, OVERLAP, AND COST OF QUALITY JOURNAL SUBSCRIPTIONS IN COMPUTER SCIENCE}

\section{Serials' Problems}

The importance of journals in the initial stages of research has been much emphasized (Lofthouse, 1974; Subramaniam, 1984). A Malaysian study showed that academic scientists and engineers have stressed the importance of an adequate coverage of journals for research needs and are opposed to budget cuts for serials subscriptions and to journal cancellation exercises (Zainab, 2001). The academics expressed a preference for publishing in quality journals such as those listed by the Journal Citation Report (JCR) and tended to orient their publications to an international audience in order to have their work published in reputable journals (Nederhof, et al., 1993; Ashoor and Chaudhry, 1993). A good collection of quality journals would expose academics and researchers to the quality contributions published in these journals, would make available current research findings, and would help stimulate and sustain teaching and research information needs (Wanner, Lewis, and Gregario, 1981).

Academic libraries could play a useful and supportive role by maintaining subscriptions of high impact journal titles and providing access to quality journals through an effective interlibrary loan or document delivery service. In reality, however, no one library could cover all published quality journals in any field due to budget cuts, the sharp increment of journal subscription costs, and an increasing number of titles published each year (Moline, 
1989; Sen and Mashkuri, 1997).

Libraries have taken various actions in order to cope with budget cuts and at the same time satisfy clientele demands. Some have embarked on serials cancellation exercises based on journal-use studies, joint faculty-librarians review lists of possible title cancellations, and through journal-cost studies (Barstow, 1993; Gammon and O'Connor, 1996; Ralston, et al., 1996; Parrish, 1996; Terhune and Moginot, 1996; Ferguson and Kahoe, 1996; Chrzastowski and Schmidt, 1996). Others have opted to increase or maintain access through acquisition cooperatives or consortia (Hooper, 1990; German, Kidd, and Pratt, 1997). One of the techniques used to manage serials has been to increase access to quality serials. Sittig (1996) used bibliometric techniques to identify fourteen core journals for medical informatics, and Nisonger (2000) used journal titles listed in the $J C R$ to establish subscription policies in academic libraries. This strategy focused on the acquisition of quality titles based on impact-factor scores provided by the $J C R$ and published by the American Society for Information Science and Technology (Nisonger, 1994; Altmann and Gorman, 1998; Kreider, 1999; Meadows, 2000). This method established the percentage of quality journal titles to be held in a collection in relation to the total titles listed in the JCR in a given subject field. A journal's impact factor is an estimated ratio of the total number of articles published in the journal to the number of articles published that received citations. A journal with a high impact-factor score indicates that the articles published in the journal are more likely to be cited and that the journal is regarded as a quality journal. Libraries have used the journal impact-factor scores to determine the optimum coverage of a journal collection in a specific field (Buffardi and Nichols, 1985; Wible, 1990; Nisonger, 1998; Meadows, 2000). This is often termed a journal-availability study. From the availability status of a number of collections, it is possible to identify overlap holdings of journal titles among a group of libraries in order to support the case for journal resource sharing and interlibrary-loan programmes (Knightly, 1975; German, Kidd, and Pratt, 1997; Fedunok, 1998) or for cost-benefit analyses (Barschall, 1988; Barschall and Arrington, 1988).

\section{The Availability of Quality Journals in Computer Science}

This paper explores the possibility of identifying the current availability status of quality journals in the field of computer science held at the University of Malaya Library (UML), estimating the degree of title overlap that occurs when these holdings are compared to other university libraries' holdings, and providing information on possible cost savings to lessen the impact of the rising cost of journal subscriptions. The university libraries compared are those at the Science University of Malaysia (USM), the University of Technology Malaysia (UTM), the National University of Malaysia (UKM), and the University Putra Malaysia (UPM). These universities have been selected for the following reasons:

(a) they offer undergraduate and postgraduate degree programmes in computer science and (b) they have been established for more than fifteen years. As such, the study assumes that the libraries at these universities have accumulated sufficient volumes of quality journals in computer science to serve their faculty and student information needs for teaching and research. This is an exploratory study carried out without prior knowledge of the serial holdings in all the selected universities, including the University of Malaya library. The main objectives are to ascertain holding patterns of quality journals, the degree of overlap in journal title subscriptions, and possible cost savings if the cost of subscribing to the overlap titles is shared. The study uses the ranked list of journal titles published in the science edition of the JCR (1999). The JCR lists a total of 387 titles in the field of computer science under seven categories: (a) artificial intelligence (62 titles); (b) cybernetics (16); (c) hardware and architecture (47); (d) information systems (59); (e) interdisciplinary applications (71); (f) software, graphics, programming (68); and (g) theory 
and methods (64). The study uses a final number of 301 discrete titles since a number of titles are listed under more than one category in the JCR.

The study involves the following stages: (a) checking the journal titles obtained from the $J C R$ list against the holdings at UML and (b) checking the bibliographic details of each title against the 1998 edition of Ulrich's International Periodicals Directory for information about subscription prices and full title information. Journals on order are not included, and the calculation of prices is based on those quoted in U.S. dollars in Ulrich. In this context, the price of journals includes titles in both print and electronic forms. The term overlap means two libraries acquiring the same title (Hopper, 1990). In this study, the numeral 1 is coded for a library when a title is held. The total number of journal titles in each subject category constitutes the availability of journal holdings in each library. Availability is presented in percentages that follow a scale of measuring scores ranging from $80 \%$ and above as excellent, $60-79 \%$ as very good, $45-59 \%$ as good, $30-44 \%$ as poor, and below $30 \%$ as very poor. The results indicate that UM's holdings of JCR titles is poor. When compared to the holdings of similar titles in other university libraries, UM's holdings of quality journals ranked second to UTM (Table 1). The performance of the five university libraries in the acquisition of impact-factor journals ranges from poor to very poor.

Table 1: Journal Availability in UML

\begin{tabular}{lccc}
\hline Libraries & Title Availability & \% Total Listed in JCR & $\begin{array}{c}\text { Availability } \\
\text { Measurement Scale }\end{array}$ \\
\hline UM & & & Poor \\
USM & 103 & 34.22 & Poor \\
UPM & 94 & 31.23 & Very Poor \\
UTM & 70 & 23.26 & Poor \\
UKM & 121 & 40.20 & Very Poor \\
\hline
\end{tabular}

Analysis of the availability factor according to the seven categories listed in the JCR indicates that of the university libraries in the study, UM holds the most titles in the field of information systems and computer hardware and architecture (Tables 2 and 3). The journal with the highest impact factor in Al and subscribed to by UM, UPM, and UTM is Cognitive Brain Research (IP-=2.755). UM holds the journal with the highest impact factor in the field of cybernetics (Biological Cybernetics IF=1.089). In general, UM and USM together hold the highest number of high impact-factor journals in this field.

Table 2: Journal Availability by Subject Categories in UML

\begin{tabular}{lccc}
\hline Category & UM & $\%$ & Measurement Scale \\
\hline Artificial Intelligence (62) & 13 & 21 & Very poor \\
Cybernetics (16) & 4 & 25 & Very poor \\
Hardware and Architecture (47) & 23 & 49 & Good \\
Information System (59) & 28 & 47 & Good \\
Interdisciplinary Applications (71) & 22 & 29 & Very poor \\
Software, Graphics, Programming & 26 & 38 & Poor \\
(68) & & & \\
Theory and Method (64) & 21 & 33 & Poor \\
TOTAL (387) & $137^{*}$ & 35 & Poor \\
\hline \multirow{2}{*}{ *34 titles are listed under more than one category } & &
\end{tabular}

Table 3: Journal Availability by Categories Listed in JCR 


\begin{tabular}{lccccc}
\hline Category & UM & USM & UPM & UTM & UKM \\
\hline Artificial Intelligence & 13 & 20 & 13 & 17 & 3 \\
Cybernetics & 4 & 1 & 2 & 5 & 1 \\
Hardware and Architecture & 23 & 21 & 14 & 24 & 13 \\
Information System & 28 & 20 & 17 & 23 & 16 \\
Interdisciplinary Applications & 22 & 19 & 11 & 32 & 12 \\
Software, Graphics, Programming & 26 & 31 & 20 & 34 & 11 \\
Theory and Method & 21 & 18 & 17 & 27 & 9 \\
\hline
\end{tabular}

\section{Overlap/Duplicates of Journal Titles}

To determine overlap, the list of titles in the JCR is checked against each university library's holdings, and the results reveal that more than one library holds a high percentage of the same titles. One hundred fifteen (38.2\%) titles are found to overlap among the libraries. Also, 97 titles $(32.23 \%)$ are titles held only in a single library collection, and 89 titles out of $301(29.57 \%)$ are not subscribed to (Table 4).

Table 4: Total Overlap/Unsubscribed Journal Titles in Computer Science

\begin{tabular}{lccccccc}
\hline Type of Title & Total & $\begin{array}{c}\% \text { of } \\
\text { 301 }\end{array}$ & UM & USM & UPM & UTM & UKM \\
\hline Singly Held & 97 & 32.23 & 20 & 18 & 16 & 38 & 5 \\
& & & $0.62 \%$ & $18.56 \%$ & $16.49 \%$ & $39.18 \%$ & $5.15 \%$ \\
Overlap & 115 & 38.20 & 83 & 76 & 54 & 83 & 45 \\
& & & $24.34 \%$ & $22.29 \%$ & $15.84 \%$ & $24.34 \%$ & $13.20 \%$ \\
$\begin{array}{l}\text { Not Subscribed } \\
\text { to }\end{array}$ & 89 & 29.57 & & & & & \\
\hline Total & 301 & 100 & & & & & \\
\hline
\end{tabular}

UM and UTM hold the highest number of singly-held titles, which together constitute $60.41 \%$ of the total titles. Of this number, UTM holds 38 titles. This finding corroborates other studies that indicate that the higher the percentage of journal availability in a library, the higher the percentage of unique titles held (Altman, 1972; German, Kidd, and Pratt, 1997). Even the small collection at IKM includes some singly-held titles that may be useful in a cooperative acquisition scheme.

The results show that the five university libraries in Malaysia hold many similar journal titles in computer science and that the percentage of title overlap is higher than the percentage of singly-held titles. UM and UTM have the same number of overlap titles, and together they account for $48.5 \%$ of total overlap. Table 5 indicates the overlap of journal titles held at different libraries. The total titles (212) held at the selected libraries are further analysed (301, total listed minus the 89 not subscribed to), and the results show that $45.7 \%$ of the titles are held at only one library, $21.7 \%$ are held by more than one library, and $15.5 \%$ are held by three libraries. The percentage difference for the singly-held titles and the overlapping titles is small (8.50\%).

Table 5: Overlap in Journal Titles held at Selected University Libraries

\begin{tabular}{lcc}
\hline Number of Libraries with Unique Titles & Number of Titles & $\%$ of the total \\
\hline Titles held by 2 libraries & 97 & 45.71 \\
Titles held by 3 libraries & 46 & 21.90 \\
Titles held by 4 libraries & 30 & 14.29 \\
Titles held by 5 libraries & 6 & 2.86 \\
Total & 212 & 100.00 \\
\hline
\end{tabular}


This result is similar to the findings of other studies that show a high percentage of overlap occurring among large libraries (Cooper, Thompson, and Weeks, 1975; Potter, 1982, 1986). Table 6 indicates the extent of overlap in titles on a library-to-library basis. The numbers in bold and italics represent the total number of journal titles held by that library. For example, UM has 83 titles and shares 58 of these titles in common with UTM library, 70 titles with USM, 35 titles with UPM, and 29 titles with UKM. The 58 titles that UM holds in common with UTM represents $69.88 \%$ of UM's JCR based journal titles in computer science.

Table 6: Total Overlapping Journal Titles by Library

\begin{tabular}{llllll}
\hline & UTM & UM & USM & UPM & UKM \\
\hline UTM & $\mathbf{8 3}$ & 58 & 50 & 39 & 32 \\
& & $(69.88 \%)$ & $(60.24 \%)$ & $(46.99 \%)$ & $(38.55 \%)$ \\
UM & 58 & $\mathbf{8 3}$ & 57 & 35 & 29 \\
& $(69.88 \%)$ & & $(68.67 \%)$ & $(42.17 \%)$ & $(34.94 \%)$ \\
USM & 50 & 57 & $\mathbf{7 6}$ & 35 & 28 \\
& $(64.94 \%)$ & $(74.03 \%)$ & & $(45.45 \%)$ & $(36.36 \%)$ \\
UPM & 39 & 35 & 35 & $\mathbf{5 4}$ & 21 \\
& $(72.22 \%)$ & $(64.82 \%)$ & $(64.81 \%)$ & & $(28.89 \%)$ \\
UKM & 32 & 29 & 28 & 21 & $\mathbf{4 5}$ \\
& $(71.11 \%)$ & $(64.44 \%)$ & $(62.22 \%)$ & $(46.67 \%)$ & \\
\hline
\end{tabular}

High overlap of titles (over 60\%) is also indicated in the fields of interdisciplinary applications, information systems and software, graphics, and programming. The least overlap occurs in the relatively newer fields of artificial intelligence, cybernetics, and theory and methods. The results indicate that the degree of overlap in all categories is higher than the percentages of titles held in a single library. There are, however, exceptions in the category of cybernetics, artificial intelligence, and theory and methods. The average percentage of overlap among the seven categories of computer science is $57.4 \%$.

\section{The Costs of Journal Title Overlap}

This study also calculates the prices quoted in the Ulrich Periodical Directory and the cost and percentage increase of subscribing to the journal titles by each library over the previous years (Table 7). The percentage of increment among the titles subscribed to ranges from $14.6 \%$ to $19.6 \%$ with an average percentage increase of $16.9 \%$. The cost of journal title overlap occurring in the area of computer science holdings at the UM library is calculated according to the cost of overlap in 2, 3, 4, and 5 libraries (Table 8).

Table 7: Journal Cost for Each University Library

\begin{tabular}{ccccccc}
\hline Universities & $\begin{array}{c}\text { Titles } \\
\text { availability }\end{array}$ & $\begin{array}{c}\% \text { of } \\
\text { Total }\end{array}$ & $\begin{array}{c}1999 \\
\text { (\$ USD) }\end{array}$ & $\begin{array}{c}2000 \\
\text { (\$ USD) }\end{array}$ & $\begin{array}{c}\text { Difference } \\
\text { (\$ USD) }\end{array}$ & \% Increase \\
\hline UTM & 121 & 40 & $87,721.67$ & $109,102.70$ & $21,381.03$ & 19.6 \\
UM & 103 & 34 & $79,378.82$ & $92,948.87$ & $13,570.05$ & 14.6 \\
USM & 94 & 31 & 67.386 .08 & $79,890.76$ & $12,504.68$ & 15.6 \\
UPM & 70 & 23 & $47,955.24$ & $57,401.61$ & $9,446.37$ & 16.4 \\
UKM & 50 & 17 & $40,098.97$ & $49,039.08$ & $8,940.11$ & 18.2 \\
\hline Total & 438 & & $322,540.78$ & $388,383.02$ & $65,842.24$ & \\
\hline
\end{tabular}

Table 8: Journal Overlap Costs in UM Library (UML)

\begin{tabular}{|c|c|c|c|c|c|c|c|}
\hline Rank & Titles & $\begin{array}{l}\text { Impact } \\
\text { Factor }\end{array}$ & $\begin{array}{l}\text { Subscrip. } \\
\text { Costs USD) }\end{array}$ & Rank & Titles & $\begin{array}{l}\text { Impact } \\
\text { Factor }\end{array}$ & $\begin{array}{l}\text { Subscrip } \\
\text { Costs(USD) }\end{array}$ \\
\hline
\end{tabular}




\begin{tabular}{ll}
3 & IEEE Inform Theor \\
4 & J ACM \\
5 & Commun ACM \\
6 & Artif Intell \\
7 & MIS Quart \\
8 & Inform Syst \\
9 & IEEE T Pattern Anal \\
10 & J Comput Phys \\
11 & IEEE T Image Process \\
12 & J Am Soc Inform Sci \\
13 & Comput Phys Commun \\
14 & IEEE T Neural Networ \\
15 & IEEE T Fuzzy Syst \\
16 & IEEE Network \\
17 & IEEE T Software Eng \\
18 & ACM T Database Syst \\
19 & Math Program \\
20 & ACM T Math Software \\
21 & IEEE Micro \\
22 & Int J Mod Phys C \\
23 & IEEE T Comput \\
24 & Siam J Comput \\
25 & Comput Method Appl M \\
26 & IBM J Res Dev \\
27 & Med Biol Eng Comput \\
28 & ACM T Progr Lang Sys \\
29 & IEEE Software \\
30 & IEEE Expert \\
31 & IEEE T Parall Distr \\
32 & IEEE T VLSI Syst \\
33 & Perform Evaluation \\
34 & IBM Syst J \\
35 & Scientometrics \\
36 & Computer \\
37 & Int J Hum-Comput St \\
38 & J Logic Program \\
39 & Inform Manage \\
40 & Microproc Microprog \\
41 & Comput Meth Prog Bio \\
42 & J Inform Sci \\
& \\
\hline
\end{tabular}

\begin{tabular}{|c|c|c|c|c|c|}
\hline 2.083 & 470.00 & 45 & Comput Chem Eng & 0.54 & $1,913.00$ \\
\hline 1.703 & 200.00 & 46 & Comput Aided Geom D & 0.513 & 541.00 \\
\hline 1.698 & 114.00 & 47 & IEEE T KnowI Data En & 0.513 & 660.00 \\
\hline 1.608 & $1,895.00$ & 48 & ACM Comput Surv & 0.484 & 100.00 \\
\hline 1.548 & 90.00 & 49 & Mach Vision Appl & 0.471 & 276.85 \\
\hline 1.547 & $1,194.00$ & 50 & AT \& T Tech J & 0.438 & 84.00 \\
\hline 1.417 & 870.00 & 51 & IEEE Comput Graph & 0.426 & 510.00 \\
\hline 1.377 & $3,674.00$ & 52 & Comput Biol Med & 0.422 & $1,081.00$ \\
\hline 1.364 & 650.00 & 53 & Comput Geosci & 0.412 & $1,563.00$ \\
\hline 1.35 & $1,518.00$ & 54 & Software Pract Exper & 0.396 & $1,970.00$ \\
\hline 1.302 & $4,269.00$ & 55 & Inform Process Manag & 0.366 & 919.00 \\
\hline 1.28 & 550.00 & 56 & Int J Intell Syst & 0.354 & $1,771.00$ \\
\hline 1.239 & 350.00 & 57 & Comput Networks ISDN & 0.329 & $1,328.00$ \\
\hline 1.159 & 185.00 & 58 & Bell Labs Tech J & 0.317 & 84.00 \\
\hline 1.153 & 860.00 & 59 & Networks & 0.306 & $1,238.00$ \\
\hline 1.125 & 149.00 & 60 & Math Syst Theory & 0.3 & 339.00 \\
\hline 1.052 & 415.30 & 61 & Comput Math Appl & 0.28 & $3,010.00$ \\
\hline 1.032 & 124.00 & 62 & ASLIB Proc & 0.263 & 252.00 \\
\hline 0.992 & 480.00 & 63 & Int J Parallel Prog & 0.255 & 984.00 \\
\hline 0.962 & 481.00 & 64 & IEEE T Reliab & 0.242 & 225.00 \\
\hline 0.958 & 935.00 & 65 & Comput J & 0.239 & 655.00 \\
\hline 0.958 & 448.00 & 66 & Eng Appl Artif Intel & 0.235 & 872.00 \\
\hline 0.933 & $5,964.00$ & 67 & Sci Comput Program & 0.231 & 867.00 \\
\hline 0.93 & 205.00 & 68 & Kybernetes & 0.194 & $5,368.65$ \\
\hline 0.856 & 396.00 & 69 & IEEE Comput Appl Pow & 0.184 & 155.00 \\
\hline 0.839 & 105.00 & 70 & J Syst Software & 0.181 & $1,254.00$ \\
\hline 0.82 & 520.00 & 71 & IEE P-Comput Dig T & 0.181 & 822.00 \\
\hline 0.815 & 480.00 & 72 & J Comput Civil Eng & 0.174 & 205.00 \\
\hline 0.766 & 750.00 & 73 & Inform Software Tech & 0.167 & 681.00 \\
\hline 0.733 & 450.00 & 74 & Inform Technol Libr & 0.148 & 60.00 \\
\hline 0.718 & $1,225.00$ & 75 & Comput Humanities & 0.126 & 192.60 \\
\hline 0.71 & 90.00 & 76 & Byte & 0.125 & FREE \\
\hline 0.71 & $1,157.00$ & 77 & Theory Comput Syst & 0.116 & 301.00 \\
\hline 0.687 & 785.00 & 78 & Math Comput Simulat & 0.076 & $2,418.00$ \\
\hline 0.685 & $1,343.00$ & 79 & Datamation & 0.079 & 75.00 \\
\hline 0.675 & $1,047.00$ & 80 & Ind Manage Data Syst & 0.078 & $5,224.00$ \\
\hline 0.674 & 382.00 & 81 & Robot Cim-Int Manuf & 0.068 & 843.00 \\
\hline 0.667 & 997.00 & 82 & Data Knowl Eng & 0.048 & $1,154.00$ \\
\hline 0.664 & $1,138.00$ & 83 & Future Gener Comp Sy & 0.019 & 661.00 \\
\hline 0.634 & 233.00 & 84 & TOTAL (\$USD) & & 79.650 .40 \\
\hline
\end{tabular}

The total cost of overlap for journal titles for the UM library is calculated as $\$ 79,650.40$. If two libraries subscribe to the same title, the cost will double to $\$ 159,300.80$. The cost will triple when overlap occurs with a third library. Of the 83 titles in the UM library, 27 titles are held in two libraries, 22 titles in three libraries, 28 titles in four libraries, and six titles in five libraries. Hence, the 27-title overlap costs approximately U.S.\$56,541.00. The 22-title overlap costs each library U.S.\$20,876.60, resulting in an overlap cost of U.S.\$62,629.80.

The 28-title overlap would cost the four universities U.S.\$112,105.20 each. Overall, the cost of overlap would cost U.S. $\$ 163,170.60$. The cost of escalating journal prices could be reduced if the libraries operated as a consortium. If each library were to purchase one title listed in the $J C R$, the total sum saved would be about U.S. $\$ 79,440.40$ or RM301,873.52. This would provide a saving in costs of about $48.69 \%$. The saved sum could be used to purchase other titles not currently subscribed to. The JCR list reveals that there are 84 titles not subscribed to by the five libraries with an estimated total subscription cost of U.S. $\$ 41,440.32$. This represents half of the saved costs of U.S.\$79,440.40. All 84 titles could be subscribed to if the five libraries were to embark on a cooperative acquisition venture, which would inevitably result in more complete coverage of high impact journal titles in the field of computer science.

\section{Conclusion}

Generally, the level of computer science journal title availability in UML is poor. The level of availability in the other university libraries is similar. Out of 212 titles available, $54.24 \%$ (115 titles) overlap. When the measuring score is applied, the total availability of JCR listed journals ranges from $16.6 \%$ to $40.2 \%$ with an average of $29.10 \%$. This falls within the rating-score range of poor and very poor, indicating poor coverage of high impactfactor journals in computer science in Malaysian universities. This situation implies poor availability of quality journals to serve researchers in this field. The three university libraries with the strongest coverage of quality journals in computer science are UTM, UM, and USM. 
The study reveals that the number of overlapping titles increases for the university libraries with high percentages of journal availability. Potter $(1982,1986)$ reports similar findings. The present study also indicates that the larger the size of a library's journal collection, the higher the percentage of its singly-held titles. The high overlap and number of singly-held titles available may be due to a number of reasons: (a) it reflects the overlap in degree programmes in computer science being offered by these universities, and overlap is to be expected among libraries that support similar user needs (Moore, Miller, and Tolliver, 1982); (b) the subscription costs of the overlap titles are generally low enough (below RM2000) to be affordable; and (c) there is a lack of cooperation among these libraries in terms of serials acquisition. The study of the UML periodicals in the field of computer science reveals possible savings in subscription costs if the library does not subscribe to titles subscribed to by other university libraries. The study on monograph consortium acquisition ventures by Moore, Miller, and Tolliver (1982) indicates that even though overlap would still exist, the extent of singly-held title holdings would also increase to an average of $54 \%$. Collection diversity, greater access, and higher user rates are achieved in such a cooperative venture (Fjallbrant, 1984; Rutledge and Swindler, 1987; Strubbe, 1989).

This finding is based on the status of journal holdings for the year 2001. Since then, a number of the university libraries have increased their subscriptions to electronic versions of journal titles. These subscriptions to electronic titles reveal overlap among library collections. Caldwell and Ellingson (1979) found a journal overlap of $28 \%$ in ERIC with $21 \%$ in Psychological Abstract. The study indicates, however, that each database has its own strengths. ERIC, for example, is more useful for papers on practical applications and applied settings while Psychological Abstract is more useful for articles related to clinical settings as well as for foreign materials. Electronic journals increase access for libraries through consortium ventures where full-text access is made available to all members. Perhaps overlap could be reduced by each member library subscribing to different journal hosts so that more quality journal coverage could be achieved.

The findings also indicate an unplanned acquisition of journal titles as reflected by the high number of journal duplicates and overlap. A cooperative acquisition venture could not only provide wider coverage of high impact titles but also allow each library to specialize in the acquisition of journal titles in any field of knowledge. This would help increase the range of titles available and the possibility of adding more singly-held titles, thus assisting libraries in overcoming the problem of decreasing subscription power. Even though the budget for serials has been increased over the years, there has been a gradual reduction in the number of subscriptions to quality titles. This has encouraged several university libraries to participate in cooperative ventures in the acquisition of electronic journals. One example is PERDANA (National digital libraries project), which allows member libraries to negotiate collectively with serials vendors for discounts and to develop a union list of participating libraries' holdings. This type of venture would indeed increase access to a wider range of quality titles.

\section{References}

Altman, E. (1972). Implications of title diversity and collection overlap for interlibrary loan among secondary schools. Library Quarterly, 42(2), 177-194.

Altmann, K.G., \& Gorman, G.E. (1998). The usefulness of impact factors in serial selection: A rank and mean analysis using ecology journals. Library Acquisition: Practice \& Theory, 22(2), 147-159.

Ashoor, M.S., \& Chaudhry, A.S. (1993). Publication pattern of scientists working in Saudi 
Arabia. International Information and Library Review, 25, 61-71.

Barschall, H.H. (1988). The cost effectiveness of physics journals. Physics Today, 41, 56-59.

Barschall, H.H., \& Arrington, J.R. (1988). Cost of physics journals: A survey. Bulletin of the American Physical Society, 33, 1437-1447.

Barstow, S. (1993). Quickly selecting serials for cancellation. Technical Services Quarterly, 19(4), 29-40.

Buffardi, L.T., \& Nichols, J.A. (1985). Citation impact, acceptance rate and APA journals. American Psychologist, 36, 1456.

Caldwell, J., \& Ellinson, C. (1979). Comparison of overlap: ERIC and Psychological Abstracts. Database, 2(2), 62-67.

Chrzastowski, T.E., \& Schmidt, K.A. (1996). Collections at risk: Revisiting serial cancellations in academic libraries. College \& Research Libraries, 57, 351-364.

Fedunok, S. (1998). Proposals for inter-institutional serials cooperation at the SUNY Centres. College and Research Libraries, 59(2), 67-77.

Ferguson, A.W., \& Kahoe, K. (1996). Friends or predators: Evaluating academic periodicals' price histories as a means of making subscription decisions. Journal of Library Administration, 24(1/2), 73-85.

Fjallbrant, N. (1984). Rationalization of periodical holdings: A case study at Chalmers University Library. Journal of Academic Librarianship, 10, 77-86.

Gammon, J.A., \& O'Connor, P. (1996). An analysis of the results of two periodical use studies: How usage in the 1990s compares to usage in the 1970s. Serials Review, 22, 35-53.

German, R.N., Kidd, T., \& Pratt, G. (1997). Serials overlap in the higher education institution libraries in Glasgow. The New Review of Academic Librarianship, 3, 115-138.

Hooper, A.S.C. (1990). Overlapping journal subscriptions as a factor in university library cooperation. South Africa Journal of Library and Information Science, 58(1), 25-32.

Knightly, J.J. (1975). Library collections and academic curricula: Quantitative relationships. College and Research Libraries, 36, 295-301.

Kreider, J. (1999). The correlation of local citation data with citation data from Journal Citation Reports. Library Resources \& Technical Services, 43(2), 67-77.

Lofthouse, S. (1974). Thoughts on "Publish or perish." Higher Education, 3, 59-80.

Meadows, J. (2000). Why do we need serials? In T. Kidd. and L. Rees-Jones(Eds.), The Serials management handbook. London: Library Association Publishing.

Moline, S.R. (1989). The influence of subject, publisher type and quantity published on journal prices. Journal of Academic Librarianship, 15(1), 12-18.

Moore, B, Miller,T.J., \& Tolliver, D.L. (1982). Title overlap: A study of duplication in the University of Wisconsin System libraries. College and Research Libraries, 43(1), 14-21.

Nederhof, A.J., et al. (1993). Research performance indicators for university departments: A study of an agricultural university. Scientometrics, 27(2), 157-178.

Nisonger, T.E. (1994). A methodological issue concerning the use of Social Science Citation Index, Journal Citation Reports impact-factor data for journal ranking. Library Acquisition: Practice \& Theory, 18(4), 447-458.

Nisonger, T.E. (1998). Management of serials in libraries. Englewood, Colo.: Libraries Unlimited.

Nisonger, T.E. (2000). Use of the Journal Citation Report for serials management in research libraries: An investigation of the effect of self citation on journal rankings in library and information science and genetics. College \& Research Libraries, 61(3), 263-275.

Parrish, M.M. (1996). Deselection of inactive serials or what to do when its already dead. Serials Review, 22, 49-59.

Potters, W.G. (1982). Studies of collection overlap: a literature review. Library Research, 


$$
\text { 4(1), 3-21. }
$$

Potters, W.G. (1986). Collection overlap in the LCS network in Illinois. Library Quarterly, 56(2), 119-141.

Ralston, R., Broadwater, D., \& Cargille, K. (1996). Automating journal use studies: A tale of two libraries. Serials Librarian, 28(3/4), 349-253.

Rutledge, J., \& Swindler, L. (1987). The selection decision: Defining criteria and establishing priorities. College and Research Libraries, 48, 123-131

Sen, B.K., \& Mashkuri, Y. (1997). The ever widening gap. University News, 35(8), 11-14, 18.

Sittig, D.F. (1996). Identifying a core set of medical informatics serials: An analysis using the MEDLINE database. Bulletin of the Medical Library Association, 84, 200-204.

Strubbe, L.A. (1989). Characteristics of serials duplication within an academic research library. Library \& Information Science Research, 11(2), 91-108.

Subramaniam, K. (1984). Research productivity and breadth of interest of computer science. Journal of the American Society for Information Science, 34(1), 75-85.

Terhune, S., \& Moginot, B.J. (1996). Periodical collection management in the college library. Christian Librarian, 39, 8-17.

Ulrich's periodical directory. (1999). New York: Bowkers.

Wanner, R.A., Lewis, L.S., \& Gregario, D.I. (1981). Research productivity in academia: A comparative study of the sciences, social sciences and humanities. Sociology of Education, 54, 238-253.

Wible, J.G. (1990). Comparative analysis of citation studies, swept use, and ISI's impact factors as tools for journal deselection. In Robert W. Burkhart \& Joyce C. Burkhart, (Eds.), IAMSLIC at a crossroads: Proceedings of the $15^{\text {th }}$ Annual Conference (pp. 109-116). International Association of Marine Science Libraries and Information Centres.

Zainab A.N. (2001). Exploring the factors related to academic publication productivity among selected Malaysian academic engineers and scientists. Thesis (Ph.D.). Loughborough University, 2001. 